City University of New York (CUNY) CUNY Academic Works

\title{
The Missing Child in A Midsummer Night's Dream
}

Thomas R. Frosch

CUNY Queens College

\section{How does access to this work benefit you? Let us know!}

More information about this work at: https://academicworks.cuny.edu/qc_pubs/142

Discover additional works at: https://academicworks.cuny.edu

This work is made publicly available by the City University of New York (CUNY).

Contact: AcademicWorks@cuny.edu 


\section{The Missing Child in A Midsummer Night's Dream}

The Indian boy over whom the king and queen of fairies quarrel is the most important of several characters in A Midsummer Night's Dream who do not appear on stage: his parents, who form with him a missing nuclear family; a child god, Cupid; and a female authority figure, the dowager to whose property the lovers Lysander and Hermia flee. In its narrative structure the play presents a healing regression to the early mother and the primary process. However, the regressive movement has disturbing, as well as adaptive, elements; in addition, while the characters are still in the forest, the play's troubled engagement with fathers has not yet been resolved. The burlesque performance of "Pyramus and Thisbe" disarms the attachment to childhood, presenting regressive modes of thought and behavior in absurd form, and thus helps complete a return to the world of the mature ego; the final act also reconstitutes the image of the father. But adult demystification and even a benign fatherly authority also appear limited, and the fairies return, bringing elements of childhood needed for a happy ending. Puck's epilogue suggests what Winnicott calls the infant's transitional experience, with its healing realm of play between dreams and objective reality, between enchantment and demystification. In the fairies' blessing, the missing child appears, still in absent form, as a child to come, a symbol of potentiality. Looming over that symbolic child is the Indian boy of Greek myth, the child god Bacchus. The play ends with a comic vision of a positive future and of amity with the often disturbing regressive elements still alive within adult psyches. Overriding the ironic and dark notes that recent critics have stressed in the play, that comic vision recreates for us a new beginning, including the new beginning of love, in the promise of a wished-for child.

The plot of A Midsummer Night's Dream depends on several characters who never appear on the stage: the dowager, to whose property Hermia and Lysander flee; Cupid, whose poor aim contributes to the confusion in the forest; and the Indian 
boy, who is the cause of the quarrel upon which much of the action depends. Also absent are the boy's mother, who died in childbirth, and the Indian king from whom he has been stolen and who may thus be his father. The Indian boy is a particular gap; as William C. Carroll writes, "This unseen but suggestive changeling . . f figures as one of the chief mysteries of the play" $(1985,172) .{ }^{1}$ I would like to study that mystery in conjunction with the other conspicuous absences that loom in the background of the action: a female authority figure, a child god, and a nuclear family.

Commentators nowadays tend to treat Shakespeare's apparent celebration of the emerging patriarchal nuclear family of his time with deconstructive irony, but I wish to focus on the comic qualities of his vision of both the family and, especially, the child. Shakespeare's complex portrayal of childhood and the childlike underlies what Marjorie Garber calls the play's "movement from court to wood and back" (1974, 70), as well as its famous thematic treatment of imagination. In focusing on the child, I will be bringing to the foreground a theme that is implicit or not fully developed in the many commentaries on the play that discuss oedipal and preoedipal dynamics, dreams, Bottom's childlike character, and the maturation of the lovers. I will be analyzing a psychological development in the play from an idealized voyage back to childhood to a return to a reconstituted adulthood and then, in the least studied part of the play's narrative structure, to a new and different idealization of childhood. Such an analysis needs to include the strategies by which the play moves from one part of that development to the next, for this is a play in which problems are solved in a way that raises new problems that then need to be solved. In studying the play's development, its treatment of childhood, and its central symbolism of the missing child, I will make use at different points of Freud, the ego psychology of Heinz Hartmann, the object relations theory of D. W. Winnicott, and Jung-influenced myth criticism.

The play begins with adults, Theseus and Hippolyta, and then moves to adolescents, the four lovers. It next moves to the craftsmen, who, with their naïveté, their misuse and mispronunciation of words, and their confusions of male and female, animate and inanimate, and make-believe and reality, are child- 
like adults. In the fairies, who can fly and who live in a world of magic, we see the spirit of early childhood, especially in Puck, who can instantly transform anything, including himself, into anything else. ${ }^{2}$ The play's regressive structure culminates when the lovers all finally fall asleep in act 4 . In a parallel development, Bottom becomes like an infant in Titania's bower, where he is fed, lovingly tended to, and treated as, to use the phrase Freud quotes in "On Narcissism," "His Majesty the Baby" (1914, 91). ${ }^{3}$ Having returned to the spirit of infant narcissism, Bottom too falls asleep. The regression is a response to obstacles and frustrations in the adult world of Athens, and we might see the play as offering a magical, romantic, wishful view of regression. At the same time, Heinz Hartmann writes that there are successful adaptations to reality "which use pathways of regression," for example, a "detour through fantasy" that can lead to an advance in thought $(1939,36)$. In A Midsummer Night's Dream, we see such a regressive detour to solve problems in the real world. A failed, rigid, unsatisfying adult order is broken down, and we go back to the beginning to start again.

Relatedly, the action moves from an Athens ruled by harsh fathers to a world of female and maternal power. Lysander and Hermia run away to find freedom beyond the reach of Athenian law at the home of Lysander's dowager aunt, this after Theseus has complained that waiting for the new moon, when his wedding will take place, is like waiting for the death of "a step-dame or a dowager / Long withering out a young man's revenue" (1.1.5-6). ${ }^{4}$ The dowager, a female authority figure without a husband, presides over a realm antithetical to Athens, as the mother presides over the world of early childhood.

Although the two lovers never literally reach the domain of the dowager, they do so symbolically in the forest. While the fairies are ruled by a male, Oberon, he depends upon female power: he uses a potion extracted from a flower that once, as Weston A. Gui points out $(1952,261-62)$, had the suggestive color "milk-white" (2.1.167), and when he originally sees Cupid accidentally shoot the flower, he has been listening to a mermaid's song that makes "the rude sea [grow] civil" and stars shoot "madly from their spheres" (2.1.152-53). In addition, Titania has rebelled and established her own realm of female power in the woods, and when Bottom is expelled from that 
realm he pays tribute to it with words that, as is well known, are a confused version of St. Paul's tribute to God. ${ }^{5}$ It is as if he were expressing a vision of an alternate, maternal divinity.

As many commentators have noted, Titania is a name Ovid uses for Diana. Another of Diana's names appears in the lovers' plan to escape into the forest "when Phoebe doth behold / Her silver visage in the wat'ry glass" (1.1.209-10). The moon goddess Diana, in addition to being a virgin goddess of the forest, was also a goddess of childbirth, and she was originally one of the great Near Eastern mother goddesses. ${ }^{6}$ The play thus moves from the bad father to the good mother; we see the fantasy that contact with the primal mother is healing, that our problems would be solved if only we could go back to the mother for, as it were, one more drink of milk. And although the intoxicating magical potion that is associated in the play with the son of the goddess of love makes things worse before they get better, it ultimately leads to a harmonious outcome.

The forest scenes have other characteristics of early childhood in addition to the predominance of the mother. What Patricia Parker analyzes as the "verbal scrambling" of the craftsmen $(1996,101)$; what C. L. Barber $(1959,129)$ portrays as a sudden failure of names when the stunned Hermia asks, "Am not I Hermia? Are not you Lysander?" (3.2.273); what Carroll $(1985,150)$ points to when Bottom turns Cobweb into an object, telling the fairy that he will need him if he cuts his finger (3.1.176-77); what Jan Kott describes as a transposition of the high and the bottom, in Bottom's translation to the status of a holy fool (1987, 40-41); what Garber describes as displacement, condensation, and "visual punning" (that is, plastic representation) in the imagery of the play $(1974,73-74,77)$ : all these are examples of the primary process, the mode of thinking characteristic of early childhood. In the primary process all of us play all the roles, as Bottom wishes to do in Peter Quince's play. The fluidity of desire in the primary process, in addition, is suggested when Helena calls Cupid a child "Because in choice he is so oft beguil'd" (1.1.239).

In the forest, as well, appear suggestions of polymorphous perversity, culminating with bestiality in the relationship of Titania and the transfigured Bottom. We also find voyeurism and sadism in Puck; sadism and masochism in Oberon (Bottom's 
references in Titania's bower to cuckoos make it hard not to wonder if Oberon is arranging his own cuckolding); masochism in Helena, who tells Demetrius to treat her like his spaniel; orality and autoerotism in Bottom in the bower; ${ }^{7}$ and homoeroticism in Helena's ardent invocation of childhood oneness with Hermia ("we grew together, / Like to a double cherry" [3.2.208-9]) and perhaps in Oberon's unyielding wish to have the Indian boy as his page, like a Ganymede. The forest voyage exposes the roots of eros in infantile sexuality. Athens is a world of intense, embattled, and unfulfilled erotic impulses, and the heterosexual love of the characters has to be rebuilt from the bottom, or Bottom, up.

In the bower, Bottom wants to be scratched and fed-he asks for a "bottle of hay" (4.1.33) — and then go to sleep, while Titania is both maternal and libidinous. As Jan Lawson Hinely has stressed (1987, 120-21, 134-36), the mother's libidinal impulses toward the male child are a decisive factor in this situation, just as the father's libidinal impulses toward the daughter may figure in Egeus's interference in Hermia's love life. Shakespeare portrays the parental participation and even initiative in the oedipal situation vividly enough that we might call the mother's mingling of genital and maternal impulses toward the son and her fantasy of possessing him forever as child/lover the "Titania complex."

Here regression has produced a major problem, for from the child's view that complex is confining as well as attracting: "Out of this wood do not desire to go," Titania tells Bottom; "Thou shalt remain here, whether thou wilt or no" (3.1.145-46). Further, the return to the mother culminates in her loss and in a symbolic castration, as Oberon has Puck take off Bottom's ass's head. The power of the mother, infused with oedipal and preoedipal fantasy, is associated not only with extreme pleasure but also with pain and destruction-and insult too, since Titania doesn't just turn away from Bottom to Oberon but rejects him with loathing.

In his famous speech on his dream, Bottom, still very much operating in the primary process ("The eye of man hath not heard, the ear of man hath not seen" [4.1.209-10]), plans to sing his song about his dream at "her death" at "the latter end of a play, before the Duke" (4.1.215-17), that is, "Pyramus and 
Thisbe." By not explicitly naming Thisbe, Shakespeare produces an association between the death of Thisbe and the loss of the mother figure Titania. "Her" is not only the loved woman who actually dies in Pyramus's life but also the loved woman who figuratively dies in every child's life. In his own buffoonish way, Bottom touches on the sadness of childhood, even evoking a deep mourning and longing that people have to overcome before they can achieve the happiness in adult love that is the goal of the voyage into the forest. In this speech too, in which, with his application of St. Paul to a female divinity, Bottom makes unwitting contact with the sublime and which has led critics to characterize him as a visionary in spite of himself, Bottom comes close to running away with the play. ${ }^{8}$ The play cannot leave us taking Bottom too seriously. Nor can it end with the power of the mother as something to be either yearned for or feared, much less thought of, in even the most whimsical way in the $1590 \mathrm{~s}$, as a possible rival to the father God.

In reaction against the father, the play has turned not only to the mother but also to female powers and gynocentric subcultures in general. Before the first scene the Amazons have been defeated, and, as Louis Montrose notes (1996, 132-34), in the first scene mothers are nowhere to be found in a world of powerful fathers. But the play follows with a series of figures of female power and autonomy: not only the moon, the dowager, and the rebels Hermia and Titania, but also the "imperial votress" who does not want or need men and cannot even be struck by Cupid's arrow (2.1.163), the intense friendship of Titania and the Indian boy's mother, and the intense past friendship of Helena and Hermia.

But perhaps more deeply subversive of the patriarchal order than either female autonomy or female bonding is the subculture of the mother and the son on whom she lavishes all her love, for in this case the female has taken away one of the males into her service. This is the pair that appears recurrently and charismatically throughout Western patriarchal culture, sometimes to be worshiped in sublimated form, as in the Christian Madonna and Son, but sometimes to be dreaded as in Grendel and his dam or in the contemporary stereotype of the single mother and her criminal son. The Cupid who causes anarchy in the world of A Midsummer Night's Dream belongs to such a pair. 
When that pairing, as in Titania and Bottom, provokes questions of sexuality, it raises the specter of not only the oedipal defeat of the father but also a full-scale return of the pre-patriarchal culture of the mother goddess and her son-lover. ${ }^{9}$

When Titania is cured of her intoxication with such a son figure, female power in its strongest and most threatening form is broken, and, in effect, all the other manifestations of female power in the play are dispelled. But female power has been shown in the play to be valuable and healing, as well as dangerous; the "sea-maid's music" (2.1.154) disordered the stars, but it also tamed the rude sea. It still remains for Shakespeare to find a place for female and maternal power, while making sure that power doesn't, like Bottom's melancholic and visionary qualities, run away with the play. In the deep structure of the play, solutions produce new problems, driving the play forward.

At the end of act 4 the world once again belongs to the fathers. Theseus, newly happy with Hippolyta, with whom he has discovered a common interest in hunting and dogs, and sympathetic to the young lovers, is a changed father figure. Oberon, however, is not; having crushed Titania and figuratively castrated Bottom, he repeats Theseus's defeat of the Amazons and the deprival of sexuality that Theseus and Egeus threatened to inflict on Hermia by sending her, if not to death, then to a convent for the rest of her life. The full image of the father still needs rehabilitating before it can be part of a happy ending. Theseus's kindness has to be sustained, and Oberon's ruthlessness cannot be our final impression of him.

A third paternal figure in the play is the Indian king, mentioned only once (2.1.22). That the Indian boy is stolen from him does not necessarily mean that he is the boy's father, but he at least fills that position symbolically, not only because in common Freudian symbolism royal figures suggest parents but also because Shakespeare's mentioning of the Indian mother, the Indian king, and no other father logically raises the possibility of his paternity. But it is critical that we do not know for sure and that he is such a tangential, remote, and undefined figure, even among the play's several absent characters.

Titania's story of the Indian mother imitating sails that would "conceive / And grow big-bellied with the wanton wind" (2.1.128-29) recalls ancient myths in which the wind, rather 
than any male, is responsible for fertilization. ${ }^{10}$ The absence of the Indian king and of a definite father for the boy suggests the unacknowledged paternity in prepatriarchal culture and the shadowy father of the preoedipal period. ${ }^{11}$ But in a play that begins with bad fathers, it also suggests the missing good father whom a child might wish for. Insofar as the Indian king may be the boy's parent, moreover, the play creates the situation of an aggrieved father; his child has been stolen from him, and we might imagine his sadness and desire. Beneath the manifest desire for a particular child in Oberon and Titania is a more general wish for a child.

Another father in the play, and the only actual father to appear on stage, is Egeus. It is surprising that relatively few critics have thought it worthy of discussion that Shakespeare gave to Hermia's father the well-known name of Theseus's own father. ${ }^{12}$ Ovid tells the story of how Aegeus mistakenly tries to poison Theseus and the more famous story of how Theseus causes his father's death, when he forgets to signal his safe return to port and his father in grief jumps to his death into a sea thereafter called the Aegean. In a play filled with errors-those of Puck and Cupid as well as those of the craftsmen-the dreadful errors in the relationship of Theseus and Aegeus are certainly relevant, and Shakespeare's choice of name, if it is not intentional, seems like a classic Freudian parapraxis. What it reveals is murderous hostility toward the father, who not only stands in our way but also would like to kill us. At the end of act 3, if the fathers need to take back their authority, at the same time the aggressive impulses of the children toward the father still have not been slaked. The story of Theseus is conspicuously incomplete if Egeus is still alive.

In act 4 Egeus is eliminated, not appearing at the festivities of act $5 .{ }^{13}$ Many modern critics may not like Theseus, but he is clearly not the play's bad father. That is Egeus, who is the spoilsport in the midst of potential happiness and the scapegoat for the evils in the world of the play; and in symbolically killing him off, the play satisfies the lingering impulse to punish and get rid of the father. The production of "Pyramus and Thisbe" that follows will remind us why he had to be eliminated, because it is, as Hinely says, "a patriarchal tragedy" $(1987,129)$, in which two young lovers are separated by their fathers. The play's ideal, 
however, is not a fatherless world but a good father, and, indeed, an emphasis on the father is needed to balance the extreme emphasis on the mother in the forest adventure.

The play must now build up that image of a good father. Oberon reminds us of Theseus's notorious reputation for promiscuity, rape, and abandonment of women (2.1.77-80). Having begun the play as a ravisher of women and an enforcer of patriarchal and anti-instinctual restrictions, Theseus has attained companionship with Hippolyta and thoughtful flexibility in governance. The father is, first of all, a reformed villain. Act 5, while showing his new qualities in action, adds other characteristics to the imago of the good father. The authority figure now acts on behalf of the pleasure principle, decreeing entertainment and deciding on ways for his people to pass the time enjoyably. Although he plays an authoritarian role that makes anything he says inherently condescending, within that role he shows sensitivity when he argues against the dismissal in advance of the efforts of the craftsmen by Hippolyta and Philostrate: "For never anything can be amiss / When simpleness and duty tender it" (5.1.82-83). And he compliments the players after their performance. When he jokes with Lysander and Demetrius during the play, he is treating them if not as equals then at least on a friendly footing. The father is not a fearsome figure; he lets the children grow up.

The burlesque "Pyramus and Thisbe" that the craftsmen now perform takes a major role in the handling of the play's unresolved and newly created problems. Garber (1974) writes that it "absorbs and disarms the tragic alternative" to the happy ending (81), and Carroll (1985), noting the garbled allusions in "Pyramus and Thisbe" to such tragic lovers as Leander, Hero, Cephalus, and Procris, writes similarly of a "comic detoxification" of the destructive possibilities in the story of the Athenian lovers (163). ${ }^{14}$ But the play within the play also disarms or detoxifies the regressive impulse that found full release in the forest. In laughing at Bottom's absurd performance as Pyramus, we indirectly laugh at his oedipal incursion and preoedipal ambitions. How can we take anything about him seriously anymore? A strong oedipal or preoedipal cathexis might well be an obstacle to a happy marriage and so has to be disposed of. Bottom has already been punished for his transgressions by his 
symbolic beheading and even more by his abandonment, but his resulting sadness is a new problem that has to be handled. We cannot enter marriage in a state of mourning for the lost mother. But when Bottom sings his lament over Thisbe, "the fairest dame / That liv'd, that lov'd, that lik'd, that look'd with cheer," a lament that is also, in effect, his promised "ballad" about Titania, we are unaffected (5.1.282-83; 4.1.213). We laugh at his loss, and at loss. It was necessary to return to childhood to solve the problems of the play, but now the problem is to return from childhood, and our laughter at Bottom as Pyramus serves that psychic project.

Earlier in the play the craftsmen served to carry us along into the primary process; now they serve to disempower it. When Pyramus says, "I see a voice," and thanks the moon for its "sunny beams"; or Snug announces that "I as Snug the joiner am / A lion fell, nor else no lion's dam," at once a lion, a lioness, and a man; or the wall, with its prized "cranny" or "hole" and its "stones," is described in what Hinely $(1987,129)$ calls "a hodgepodge of vaginal, phallic, and anal allusions," we laugh at the primary process itself $(5.1 .190,261,218-19,162,198$, 188). ${ }^{15}$ Guided by the sarcasm of the aristocrats, we mock and thereby disarm the nonsensical; we see that regression is not what we really want. In "Pyramus and Thisbe," a man becomes a wall, and, as Parker notes (1996, 96), a wall becomes-when Demetrius comments that it is "the wittiest partition that ever I heard discourse" (5.1.165-66) - a division of discourse. The partitions between a man, a structure of stones, and the structure of a speech come down. The characters had to go into a state where anything was possible-where customary forms dissolved, words were mispronounced and misused and took on new and multiple meanings, and the partition between fantasy and reality fell away-before they could get what they wanted.

But in the play's vision regression is a detour to realistic goals, not an end in itself, and so we laugh at a time when we couldn't pronounce words correctly, when we moved fluidly among erogenous zones, when it was easy for us to pretend to be lions or walls or moonshine. We laugh too at a time when we were unsure of the difference between a lion and a lioness: in the play within the play, Snout has a phallic name but plays a wall with a hole in it, and Bottom refers to his own "pap" 
(5.1.286). And when Thisbe tells Pyramus, "My cherry lips have often kiss'd thy stones" and "I kiss the wall's hole, not your lips at all” $(5.1 .188,199)$, polymorphous perversity is reduced from phantasmagoria, as in the forest, to slapstick.

In laughing at childhood and its fantasies and ways of thinking, we laugh at the figure that once ruled that realm, the omnipotent mother. The play within the play has evil fathers but no mothers at all; Bottom, after participating in an adventure dominated by a mother figure, now participates in a second adventure in which the mother is eliminated. Indeed, the cast of "Pyramus and Thisbe" was to have included Thisbe's mother, as well as both fathers; these parts were deleted, but at least the fathers are still mentioned. Conversely, this parody of the main action has no dowager, no supernatural beings from the world of nature, and no son of Venus, and that absence of symbols or representatives of the mother might be a factor in turning a comedy into a tragedy; but we laugh at the tragedy of a motherless world even as we gain psychological benefit from the elimination of the mother.

Perhaps the silence of Hermia and Helena during the performance, in addition to being a sign, as Parker says, of their integration into a male-dominated order as subservient wives $(1996,106)$, is another expression of a downplaying of the female that is psychologically here an attempt to tame and break free of the mother. ${ }^{16}$ Verbal traces of the mother are discernible in "Pyramus and Thisbe," but their function is to provoke laughter. In the jokes about Bottom's pap and the lion's dam, the mother appears in absurd, rather than reverent or elegiac, contexts. When Bottom appeals in jingling meter to the "Furies fell" and the Fates who "Cut thread and thrum" $(5.1 .273,275)$, these powerful and fearsome female authority figures are robbed of their menace. When Thisbe speaks of the "Sisters Three," who have "hands as pale as milk" and who have shorn "With shears his thread of silk" (5.1.323, 325, 328), the mother who castrates the weaver Bottom with his own shears is comical, not terrifying.

Similarly, a sequence of jokes about the moon reduces the divine moon mother, who presided over the nocturnal world of the forest, to an object of laughter. When the Moon, carrying a lantern, calls himself the man in the moon, and Theseus says that 
then "the man should be put into the lantern" (5.1.237-38), we are laughing at the idea of the fetus in the womb. The Amazons of myth were devotees of Artemis, who was associated with the moon, and Shakespeare's Hippolyta invokes the moon in her opening speech, but even Hippolyta is "aweary of this moon" in "Pyramus and Thisbe"; that moon is not only wearisome but also, deprived of its traditional femaleness, a "he" (5.1.242). In all these ways, then, the play within the play works to make sure that the power through which the characters found their happiness at the end of act 4 does not become warping in itself.

The detachment from the regressive ambiance of the forest takes another form, as well. Wondering about the events in the forest, Theseus dismisses the tales of the lovers and brackets lovers in general with poets and madmen as victims of the "tricks [of] strong imagination" (5.1.18); he is a rationalist who does not believe in "antique fables" or "fairy toys" (5.1.3). Hippolyta, though, observes that the consistency of the lovers' stories argues for something more "than fancy's images" (5.1.25). Together, they show the important ego function of reality testing, of distinguishing fantasy from objective reality. That concern continues during the play within the play, as the aristocrats make fun of the over-literalness of the players; in doing so, they are calling attention to the borders between reality and make-believe that seemed to dissolve in the dreamlike experiences in the forest. These confusions led people to violent emotions in the forest; here they are laughed at. The main function of all the aristocrats in their comments about strangeness and dramatic representation is to distance fantasy and imagination and to assert the ego's grasp of objective reality.

In the play's dynamic structure, in which solutions to problems raise new problems to be solved, that is what is appropriate at this phase of the action, unless we think that it would be a good thing to stay in the forest permanently and that the ego and a clear sense of common actuality have no real value. Similarly, this is the time for secondary process thinking to assert itself, the time not for dreaming but for discussion, debate, interpretation, decision-making, and problem-solving - all functions of the mature ego that now come into play, especially in the conversation between Theseus and Hippolyta. In the play's checks and balances, demystification and secondary process demarcations 
follow an immersion in romance and redress a heavy emphasis on the primary process and childhood fluidity.

When, however, the actors themselves disrupt the theatrical illusion, as, for example, when the lion announces that he is really Snug the joiner, we laugh at reality testing carried to an absurd degree. So while demystification holds sway in this part of the play, we are also reminded that demystification itself is not above the mortal folly of which Puck famously is a connoisseur ${ }^{17}$ and that it is not the play's final word. Indeed, after the craftsmen have danced their bergomask, not only are Theseus's last words of sex and festivity-"Lovers, to bed," "A fortnight hold we this solemnity / In nightly revels and new jollity"-but they are also filled with personification, metaphor, double-entendre: "The iron tongue of midnight hath told twelve," "This palpablegross play hath well beguil'd / The heavy gait of night" (5.1.350, 355-56, 349, 353-54). Here is the mature ego not inhibiting desire but helping it to fulfillment and making a controlled use of fantasy, the primary process, and the "fine frenzy" of the poet (5.1.12). Above all, we hear the demystifier of "fairy toys" announcing, "tis almost fairy time" (5.1.350).

His last speech embodies a new stage in the growth of his ego, which integrates and makes use of elements previously devalued. But it also signals a new stage in the play's development. The emphasis on rational and satirical detachment disarms impediments to the happy coming together of lovers, but it does not create the atmosphere conducive to that union. For that we need, once again, enchantment. Even a kindly and understanding skepticism cannot be the final vision of a romantic comedy, especially one that has already, in Bottom's speech about his astonishing experience, touched, in its own unique and peculiar way, ecstasy and sublimity. We need another dose of the green world.

And so the fairies now show up, and not metaphorical ones, as in Theseus's last speech. After the demythologizing comes a remythologizing, after the dispelling, a new spell. And this time the forest comes to Athens. Theseus, it turns out, is not master in his own house; his house is filled with preternatural powers. "The rational plan must include the irrational as a fact," Heinz Hartmann writes $(1939,72)$. A place has to be made for fantasy, the marvelous, and regression; a place, as well, has to be made 
for the mother and the realm she once dominated. "Pyramus and Thisbe" thus serves both to break the spell of the powers of the forest and to prepare proleptically for their return.

Oberon and Titania now enter, hand in hand, demonstrating an "amity" (4.1.86) that has replaced their former spousal and gender wars and that augurs well for the newlyweds. The fairies have come to "bless this place," bring to it "sweet peace," and ensure that its "owner" "Ever shall in safety rest" (5.1.386, 404, 405-6). The ego may not be master in its own house, but the deep forces that exist beyond its power and conscious awareness bless that house. Then while the fairies spread out through the house, Puck remains alone on stage, and, as the craftsmen did, he explains to the audience that they are just watching a play. But while the craftsmen broke the theatrical illusion in its middle in a bumbling way, Puck deliberately brings the illusion to a graceful end:

If we shadows have offended, Think but this, and all is mended, That you have but slumber'd here While these visions did appear. And this weak and idle theme, No more yielding but a dream, Gentles, do not reprehend. If you pardon, we will mend. And, as I am an honest Puck, If we have unearned luck

Now to 'scape the serpent's tongue, We will make amends ere long;

Else the Puck a liar call.

So, goodnight unto you all.

Give me your hands, if we be friends,

And Robin shall restore amends. (5.1.409-24)

The fairies, the "shadows" of the night (3.2.347), are transformed into what Theseus earlier called actors, "shadows" of the stage (5.1.208). All the strangeness is resolved to the intelligible reality of a piece of entertainment, a play. But what is a play? What is it to be entertained? Theseus suggests that it is something "To wear away this long age of three hours / Between our af- 
ter-supper and bed-time" (5.1.33-34). But what do we seek in passing the time between food and sex? What makes that time interesting? The suggestion of an answer appears in Puck's speech. While Snug the joiner says that he is not really a lion but is really Snug the joiner, the actor who plays Puck continues through the last speech to refer to himself by the two names of his character. The illusion is maintained even while it is being dispelled. What we get is something that is neither fantasy nor reality as we ordinarily live it, something neither true nor false in the ordinary sense. Jonathan Bate suggests that the play invites us "to believe and not believe" $(1993,135)$.

But perhaps we can more clearly conceive of such a condition as a third state of being. Suggestive here is Winnicott's concept of the transitional stage in early development. For Winnicott (1971), transitional objects and phenomena, such as the infant's special blanket or its babbling, occur in an intermediate area of permissible illusion "between a baby's inability and his growing ability to recognize and accept reality" (3), "between external or shared reality and the true dream" (25). This protected space is "in direct continuity with the play area of the small child who is 'lost' in play" and also with the later "intense experiencing that belongs to the arts and to religion" (13-14). Winnicott stresses that the issue of whether the transitional object comes from within or without never arises: "It is a matter of agreement between us and the baby ... that no decision on this point is expected. The question is not to be formulated" (12; italics in original). The transitional area constitutes "the third part of the life of a human being," which exists "as a resting-place for the individual engaged in the perpetual human task of keeping inner and outer reality separate yet interrelated" (2).

Rather than answering questions about enchantment and demystification, Puck's epilogue helps us recognize that we have been in a psychological place where such answers are irrelevant. Telling us that the fairies are just actors, but still calling himself Puck and Robin and promising that he will continue to exist in that role, Puck sends us back, refreshed, to the ongoing tension between external reality and internal subjectivity but reminds us that the transitional experience will be there for us in the future.

A further factor in the transitional experience is important. Winnicott writes that the child's ability to become absorbed 
in play depends upon its trust in the reliability of the mother (1971, 47-48). Without such trust that the mother will be there when needed or will return when absent, the child would be too depressed to play. Norman Holland (1979), in trying to understand how the lovers transcend their uncertainties about each other to achieve trusting love relationships, relates the infidelities in the forest to the deep theme of the infidelity of the mother; and he further sees "a parallel between the lovers falling in love and the way the rest of us give ourselves to plays" (17). The suspension of disbelief that allows us to become immersed in a play on the stage derives from our first suspension of disbelief, in the infidelity of the mother. To play, to give ourselves to a play, to love, we must have, in Holland's Eriksonian phrase, a "basic trust" (17) that we originally developed in the early relationship with the mother.

"Pyramus and Thisbe" did not succeed in creating an intermediate space in which we could lose ourselves; indeed it was the purpose of the play at that point to dispel, not recreate, enchantment and the realm of the early mother. But after the play within the play, the spirit of the mother returns not only in the indirect form of the fairies, the creatures of the forest, but also in Puck's closing assertion of the transitional vision. If we are able to enter a fictional world and suspend disbelief in the reality of its events, that in itself implies the trusted mother. In this sense, the mother-the female power figured in the absent dowager-returns at the end as the ultimately prevailing psychological presence in the play's apparently patriarchal world. And the sense of a trusted relationship with the mother in the transitional experience becomes in Puck's speech a general trust and affection: "Give me your hands, if we be friends" (5.1.423).

But we have not yet reached the fullness of the play's comic vision or of its treatment of childhood. When Puck appears alone on the stage in the epilogue, he is what is left over at the end, what is still in power in the world of the play. Puck stands at the intersection of many of the play's themes. He is the spirit of errors, the nonsensical, dreams, the irrational, metamorphosis, the unpredictable, make-believe, illusion. We are unaware of his interventions; he is the spirit of the unconscious. He is the trickster, the figure of myth whom C. Kerényi calls the "spirit of 
disorder, the enemy of boundaries" (1956, 185; italics in original). In his playing of tricks, he is a figure of mastery, but he is also a blunderer, an $x$-factor subject to $x$-factors. He is also the spirit of early childhood. Unlike Bottom, who is a parody of a child, he is truly childlike, with his playfulness, his amorality, his love of nonsense, his ambiguous gender, his curiosity to see how people will react to finding a crab in their drinking bowl. Gui points out the frequency of "oral trickery" in his practical jokes and the "oral trauma" they cause $(1952,267)$. But coming "To sweep the dust behind the door" (5.1.376), he also has an anal element. Above all, though, with his broom, his aura of magical omnipotence, and his exuberant flying ("I'll put a girdle round about the earth / In forty minutes" [2.1.175-76]), he seems a spirit of the early phallic phase, when, as Phyllis Greenacre puts it, the little boy, with his new powers of mobility and "bodily vigor" and his sense of the erection as a "defiance of the laws of gravity," feels like "a confident Superman who can jump over houses" (1964, 232-33, 237).

We can apply to Puck what Coleridge said of Ariel, that he is like "the child to whom supernatural powers are given" (1811, 364). Coleridge's ambiguous wording is apt, because Puck is both a childlike being given supernatural powers and an emblem of the seemingly supernatural powers of the child in the world of A Midsummer Night's Dream. This is a play in which a missing child plays a role that is both marginal and central. By not putting the Indian boy on stage, as Calderwood suggests (1991, 415), Shakespeare transforms him into a symbol. But that missing, symbolic child does appear in act 5 , and not only in the figurative form of Puck. He appears, still in the form of a missing child, a child not yet born, in the fairies' blessing of the bridal beds:

And the issue there create

Ever shall be fortunate.

So shall all the couples three

Ever true in loving be;

And the blots of Nature's hand

Shall not in their issue stand:

Never mole, hare-lip, nor scar,

Nor mark prodigious, such as are 
Despised in nativity,

Shall upon their children be. (5.1.391-400)

Certainly, the wish that children not have birth defects reflects a fear of real parents now and perhaps even more so then when such defects were seen as marks of disfavor. Still, it may seem surprising that the play uses key closing moments in this way. If the child is symbolic, what is it symbolic of?

With the passage on the fairies' blessing, marriage appears not only as the end of courtship and as a complex new relationship but also as the beginning of family life. It is depicted not only as a social institution that fulfills love and, as both Freud and postmodern critics stress, that channels and regulates sexuality, but also as one that provides for the care of children. And, as it happens, not only is a child missing in the play but so is an entire family. A family in India is very far away from an English audience, but Freud $(1919,241)$ reminds us that the strange and remote can be a disguise for what is close to us. The action of A Midsummer Night's Dream begins with various figures of unhappy or unpromising family life: a rapist and an Amazon; a daughter with a cruel father and no mother; a wife, Titania, who rejects her husband sexually, while he in turn is planning a vicious trick on her. But at the end the play develops a kind of family romance, featuring loving couples and their blessed children. The family has been missing in an additional sense. In a certain way the original nuclear family disappears whenever the child turns away to the outside world and adult life, as Hermia does at the beginning of the play. The play then searches for that original family unit, going back through oedipal and preoedipal entanglements until at last it discovers, or recreates, the pristine origin of the nuclear family in the promise of the child. ${ }^{18}$

And the child who is blessed by the fairies, who will start life with no impediments and be the best that nature can make it, is not only the unborn child of each of the three couples. It is also a symbol of what is to come in general; it is the next generation; it is the future of the entire comic community, which the audience is invited to join in Puck's epilogue. It is a symbol of potentiality. It is a work of the imagination, which supposes bushes to be bears, as Theseus says, but also shapes "The forms 
of things unknown" (5.1.15) by conceiving of the possibilities of the future, in this case hopefully.

Critics remind us that what actually did come in the mythic future of Theseus and Hippolyta was disastrous. The child they had was Hippolytus. Theseus reverted to his old ways, discarded Hippolyta, and married Phaedra, who fell in love with Hippolytus and accused him of rape when he rejected her. The blessed child was cursed by his father and killed by that curse. It would be hard to imagine a more nightmarish future for characters who are supposed to live happily ever after. Was Shakespeare, by choosing these particular parents, committing a Freudian error, completely undoing his celebration of romantic marriage and a happy future? Or was he, in trying to alter the future of his two preexisting characters, seeing how far he could stretch the limits of the comic vision? Postmodern critics would prefer a more ironic and subversive understanding of the child to come, and they would be right if they said that no matter what Shakespeare might have been trying to do, the story of Hippolytus and Phaedra is so firmly ingrained in our minds that it cannot be revised out of existence. Here is Louis Montrose, putting the case for subversion in a powerful way:

The all-too-human struggle between the fairy king and queen-the play's already married couple-provides an ironic prognosis for the new marriages. . . . The play ends upon the threshold of another generational cycle, in which the procreation of new children will also create new mothers and new fathers. The ending contains within it the potential for renewal of the forms of strife exhibited at the opening of the play. The promised end of romantic comedy is not only undermined by dramatic ironies but is also contaminated by a kind of intertextual irony. . . . Oberon's blessing of the marriage bed of Theseus and Hippolyta evokes precisely that which it seeks to suppress: the cycle of sexual and familial desire, fear, violence, and betrayal that will begin again at the very engendering of Hippolytus. (1996, 145, 149)

Actually, we have no reason to believe that the marriages and children of the two other couples will not be happy. At least 
we are at liberty to conclude that some futures may work out well. But even in the case of Theseus's child, another view than Montrose's is possible. The blessing of the fairies is not a prediction or a prophecy, and let us suppose that the future does turn out exactly as in the precursor version of the story. Beyond the blessing, some marriages will end unhappily. All children will have to repeat the preoedipal and oedipal struggles of their parents and sometimes will emerge deeply wounded. All children will have to go through the adolescent struggle against the oppressive parents. Some parents will abuse their children sexually or violently. Some will unconsciously or even consciously wish them dead, and sometimes parents will actually kill their children and children kill their parents. And in a world of accidents and errors, even someone as measured and rational as Theseus, who later believes the lie of Phaedra, may make errors that turn out to be fatal; there will be mistakes that, unlike those of the craftsmen, we cannot take for "Our sport" (5.1.90).

But all of this does not invalidate marriage or the having of children or the blessings we have for the unborn. It sets those blessings in the actual world. We know things like this may happen; we know that solving problems in one generation does not mean the same problems will not arise in the next one; but we still commit ourselves to the future, to potentiality, to a comic or erotic vision in a world of Thanatos. The unavoidable allusion to Hippolytus is relevant to our understanding of the play exactly because it is an example of the worst that might happen. A blessing is not a denial; it is an act of love. The comic vision expressed in the blessing of the fairies returns us to a moment of potentiality in which the tragedy did not have to happen, and it sends us out from that moment toward our own futures and the futures of those we care for.

Yet if Hippolytus is, in a certain sense, the missing child of the play, we should note that in the Metamorphoses and the Aeneid, he was restored to life by Aesculapius and taken by Diana to one of her sacred groves, where he lived under a new name, Virbius, and, according to Frazer, became the first priest-king of the golden bough. ${ }^{19} \mathrm{~A}$ hunter and scorner of love, he had always been a devotee of Diana or Titania, and now he returned to life as her son-lover. In the child to come, we can thus see 
a continuing impulse to return to the forest, to be the child of the goddess, to be Bottom in the bower; we can see a reassertion of the bond between Titania and the Indian boy. After Theseus leaves the stage, the creatures of regression return; his Athens appears as a small place surrounded by the forest; his vision of the ego, the secondary process, and a social order is set in a larger context that includes the power of the archaic mother and the presence of early childhood, both still alive, not however subverting his order but existing in amity with it, even blessing it.

The child that the fairies bless is thus not only the child of the adult but also the child within the adult, the regressive tendencies, the playfulness, the nonsense and primal process. We come out of the regressive forest, and in "Pyramus and Thisbe" we sacrifice the childlike, but that sacrifice turns out to be proleptic, enabling the childlike to live within us in an acceptable way. For that regressive element, according to the play, has a continuing value. Without regressive energy, there would be no lunatics but no poets or lovers either. But even more basically, when we take a step forward into maturity, we detour, in the vision of the play, to the realm of the dowager; to be an adult we first have to go back to childhood, partly to receive support and revitalization from the realm of the early mother, and partly to work through unresolved problems left over in that archaic world. And if the child still in us is blessed, so is the child we were, even though that child attacked Egeus, the father, and tried to return to Titania, the mother, even though it killed off both parents in its own development toward maturity. The blessing of the fairies alleviates our guilt.

In still another of its meanings, the missing child is also the child whom we may have now but who is missing in the sense that it is never ours as much as we want it to be. As Egeus learned, the child slips out of its role as an object to serve parental gratification; it is missing as "my henchman" (2.1.121) or "my love" (3.1.164), as Oberon and Titania speak of the Indian boy and Bottom, respectively; even when Oberon at last claims to have the boy, he still is missing from the stage. We may speak not only of a Titania complex, in which the mother seeks to keep the son with her always, but also of an Oberon complex, in which the father seeks to replace the mother as the total focus of the 
son's life and have the son as his servant and second self; and the wishes of both parents are doomed to failure.

We can thus understand why the Indian boy, the cause of tempestuous conflicts that disorder nature, never appears. Shakespeare uses him to create a symbolic presence, looming over the world of the play, of the child of the future, who is still unborn; the child of the past, who is no longer visible; and the child of the present, who, after infancy, is never as much our visible possession as we want it to be. We can understand why the Indian boy is associated with a location that, for an English audience, is strange and faraway, as much so as the future, our own archaic pasts, and the independent inner world that children must eventually develop.

But why the particular faraway location of India? Pyramus and Thisbe, in the 1567 Golding translation of Ovid that Shakespeare used, live in "the East": "So faire a man in all the East was none alive as he, / Nor nere a woman maide nor wife in beautie like to hir" (4.72-73). Their story is embedded in the story of Bacchus and is told by three sisters who would not countenance "The Orgies of this newfound God" and even denied his divinity (4.2). Ovid calls Bacchus "puer aeternus" (4.18), or, as Rolfe Humphries $(1955,81)$ translates, "A boy forever." ${ }^{20}$ Golding also tells us that "all the East" obeys him "as far as Ganges goes," and he calls him Niseus, the one from Nysa in India, where the god spent his infancy $(4.26-27,17)$; Humphries calls him "The Indian" (81).$^{21}$ Here is another meaning of the Indian boy of Shakespeare's play. ${ }^{22}$ Bacchus is, in Golding's rendering, "Twice borne, the sole and only childe that of two mothers came" (4.16); after his original mother, Semele, was destroyed by the glory of Zeus, the fetus was sewed into Zeus's thigh, and after his birth he was cared for by Semele's sister and the nymphs of Nysa. In having two mothers, Bacchus is like the Indian boy, who has both birth mother and Titania, and in being twice born, Bacchus is like Hippolytus, who became Virbius, or, in Golding's note, "Twice-man" (1965, 460). ${ }^{23}$

God of regressive ecstasy and frenzy, Bacchus was, with his many names and forms and what Leonard Barkan calls his "sublime confusion" $(1986,38)$, the god of the primary process and the oceanic feeling. He is a version of the mythic archetype of the divine child, as is another child who never appears on 
stage, Cupid. Such a "Primordial Child," writes Kerényi, embodies "the divine principle of the universe at the moment of its first manifestation": "In the image of the Primordial Child the world tells of its own childhood" $(1949,43,45) .{ }^{24}$ The frequent bisexuality of the figure, as in the case of Bacchus, who has in Golding "a Maidens face" (4.25), expresses an "undifferentiated state"; through him we can glimpse "being not yet separated from non-being" (Kerényi 1949, 55, 69).

In the play, India, the East, where Oberon has just come from and where Titania spent her time with her votaress, is symbolically the place where things begin. Through the divine child, of whom the Indian boy and the children blessed by the fairies are manifestations, we make contact with origins and even perhaps with a state before origins, a state of complete possibility, or, in Wordsworth's terms from The Prelude, "something evermore about to be" (1850 version, 6.608)..$^{25}$ Although in a smaller and less sublime way, in a way that is consistent with a comedy, A Midsummer Night's Dream participates in the same archetype as Wordsworth's "Immortality Ode," in which the child is a being of glory on the shore of "that immortal sea / Which brought us hither" (1l. 163-64); Virgil's Fourth, or Messianic, Eclogue, in which "The Firstborn of the New Age" (11. 7-8) will renew the Golden Age; and Milton's "Nativity Ode," in which an "Infant God" (1. 16) appears to lead us to "our bliss / Full and perfect" (1l. 165-66). ${ }^{26}$

The childlike Puck, who now closes the play, does not appear as such a luminous figure. He's just an actor. And although, like Ovid's original Indian boy, he can turn people into animals, he is even in role a comparatively diminutive figure. Here in the epilogue he is a gentle one as well: he speaks of kindness and forgiveness and wants to be friends with us. The play at the end does not give us the sublime, the visionary, or the apocalyptic. Yet to be on peaceful and friendly terms with the childlike in ourselves and in the world outside, with the past and the future, with an $x$-factor that intervenes in our lives, is not a small thing. That amity also embodies the vision of community that is elemental to comedy: "Give me your hands, if we be friends" (5.1.423). But in its last line the play reaches beyond amity to the simple, primal ethos of comedy, leaving us with a sense of not an ending but a beginning. In A Midsummer Night's Dream the world has a future, and it is a future in which things can be 
better. If you didn't like this play, come to the next one: "And Robin shall restore amends" (5.1.424).

\author{
Department of English \\ Queens College \\ City University of New York \\ Flushing, NY 11367 \\ tfrosch@nyc.rr.com
}

\title{
Notes
}

1. Among critics who find the Indian boy central are Allen Dunn (1988), for whom the entire play embodies the Indian boy's own dream of expulsion from the maternal bower, and William W. E. Slights (1988), for whom the boy expresses the play's theme of indeterminacy. As Slights notes, the boy appears on stage in some productions, although never in the text (259).

2. E. K. Chambers calls the fairies "eternal children" $(1925,85)$.

3. Louis Montrose calls Bottom's experience "a parodic fantasy of infantile narcissism and dependency" $(1996,170)$.

4. Quotations from A Midsummer Night's Dream are taken from the Arden edition, edited by Harold Brooks (1979). In note 18 below, my quotation from The Comedy of Errors is keyed to The Riverside Shakespeare (1997).

5. The Geneva Bible (1560): "The things which eye hathe not sene, nether eare hathe heard, nether came into mans heart, are, which God hathe prepared for them that love him" (1 Corinthians 2:9). Bottom: "The eye of man hath not heard, the ear of man hath not seen, man's hand is not able to taste, his tongue to conceive, nor his heart to report, what my dream was" (4.1.209-12).

6. See Brooks on the various forms of Diana, including the "many-breasted" Diana of the Ephesians (1979, lxxxv). As is often noted, Ovid also uses "Titania" for Circe.

7. Gui finds suggestions of "masturbative genital play" $(1952,258)$ in Bottom's asking to be scratched by Titania and her fairies.

8. See, for example, Harold C. Goddard, who writes that in Bottom's speech on his dream, Shakespeare captures "the original miracle of the Imagination, the awakening of spiritual life in the animal man," and that in all his plays there are "few things more wonderful" (1951, 79-80).

9. The classic text on archaic matriarchy is Bachofen (1861), and that on the mother goddess and her dying and reviving son-lover is Frazer (1890, esp. 390-436). For a recent study of the mother goddess in both prehistory and later cultures, see Anne Baring and Jules Cashford (1991). For a psychoanalytic study of the goddess and her son-lover, particularly Cybele and Attis, see Edith Weigert-Vowin[c]kel (1938).

10. See, for example, Robert Graves's retelling of the Pelasgian creation myth, in which the north wind becomes a serpent to couple with the primal goddess; and so, it was thought, "mares often turn their hind-quarters to the wind and breed foals without aid of a stallion" (1992, 27). See also Theodor Gaster on the myth of a primal creative wind in various cultures and the "unconscious" survival of that myth in the Genesis account of the spirit or breath of God, or a "mighty wind," moving over the primordial waters $(1969,4-5)$.

11. Douglas Freake discusses "the ignorance ... about the role of the father in conception" in early Greek culture $(1998,269)$.

12. Among those who do are Freake $(1998,259)$ and James L. Calderwood (1991, 427).

13. Calderwood (1991) notes that Egeus does appear in act 5 in the Folio version of the play and speaks lines that in Quarto 1 are spoken by Philostrate. As Calder- 
wood argues, his elimination in Quarto 1 "makes far better sense ... sweep[ing] the stage clear of the harsher aspects of patriarchy" (428).

14. Anne Barton writes that the play within the play "transform [s] tragedy into farce" and distances "death and destruction ... through laughter" $(1997,254)$.

15. I differ from Hinely in my thinking that the jokes of "Pyramus and Thisbe" do not "playfully recall" $(1987,130)$ and even intensify confusions and anxieties of the forest, but comically disarm them.

16. Montrose, who sees in the play an ambivalent portrayal of the power of Queen Elizabeth, whose authority was popular but also threatening to patriarchal standards, writes that "patriarchal norms are compensatory for men's perceptions that they are vulnerable to the powers of women" $(1996,151)$. From a psychological viewpoint, I would amend that formulation to "the powers of the mother." See Janine Chasseguet-Smirgel's discussion of "paternal law" and male "scorn" of woman as motivated by "the need to detach oneself from the primal omnipotent mother" (1976, 283-84, 286).

17. "Lord, what fools these mortals be!"; "And those things do best please me / That befall prepost'rously" $(3.2 .115,120-21)$.

18. Shakespeare also explores the return of a missing child and the restoration of the family unit in plays from The Comedy of Errors through Pericles, Cymbeline, and The Winter's Tale. In those cases, a lost child is found and a previously existing family restored. Oberon, Titania, and the Indian boy form a complex variation of that situation, but A Midsummer Night's Dream ends with, and takes its distinctive spirit from, new families and a child to come. In The Comedy of Errors, in which lost, grown children are reunited with each other and with their parents, who are also reunited, the reunion is figured as a resurrection, occurring after a Christlike thirty-three years, and in the Folio it is also described as a "Nativity" (5.1.407); but critics have disputed the authenticity of that word, and some editions do not include it; see R. A. Foakes's note in the Arden edition (1962, 106).

19. Ovid tells the story in book 15 of the Metamorphoses (1l. 400-3), while Virgil tells it in book 7 of the Aeneid (11. 54-57). Frazer (1890) begins The Golden Bough with two sections called "Diana and Virbius" and "Artemis and Hippolytus" (1-10). Apart from references to Golding's translation of the Metamorphoses, all quotations from this poem and from the Aeneid are from the Loeb Classical Library editions. My quotation from the Eclogues in the text 28 below is from the Penguin edition.

20. Golding writes that his "youthfull yeares can never wast: there dwelleth ay in thee / A childhood tender, fresh and faire" (4.22-23).

21. Brooks (1979, lxxxiv) notes that Spenser mentions Oberon as a descendent of Elfin, whom "all India obayd" (The Faerie Queene, 2.10.72.5). Elfin has been identified with Bacchus; see the edition of The Faerie Queene by A. C. Hamilton (1977, 271).

22. Vicky Shahly Hartman, noting that Bacchus is called "the Indian," pursues the association in a different direction from my own: she writes that the ass is another Bacchic symbol and that the Titania-Bottom relationship alludes to the traditional sacrifice of the Bacchic figure to the moon goddess (1983, 363-64). In her reading of the play, oedipal impulses in the woods are resisted or unfulfilled in a guilt-free progress toward nonoedipal attachments. For another interpretation of the play's India, see Ania Loomba (2000), who takes the boy as a "colonial commodity" (182) and "a human subject diminished into a dream of possession" (184).

23. The myth of Bacchus's second birth from Zeus's thigh, like the myth of Athena's birth from his head, is an example of the male attempt in early culture to usurp female creative power. Montrose $(1996,132-34)$ and Parker $(1996,104)$ have noted such a usurpation in the play: Theseus tells Hermia that her father is "as a god," who "compos'd [her] beauties" and "imprinted" her "as a form in wax" (1.1.47-49). That male claim of total procreative control has to be seen together with the corresponding female claim in Titania's figurative story of the Indian mother and the fertilizing "wanton wind" (2.1.129). Both claims are problems that the play must work through before it can reach its concluding vision of procreation in which both genders participate. 
24. Making use of Kerényi and Jung, Freake (1998) describes Bottom's dreamlike experience as "a vision of the child archetype," but develops the concept differently, writing that in that vision Bottom is "allowed perhaps to indulge an appreciation of the 'female principle' that the waking man can admire only when it is firmly subordinated to male supremacy" $(266,271)$. Freake sees the play's use of the archetype primarily in terms of the struggle between male and female over possession of the child.

25. All quotations from Wordsworth are from the Poetical Works (1964).

26. My quotation from Milton is from the edition of Merritt Hughes.

\section{References}

Bachofen, J. J. 1861. Mother Right. In Myth, Religion, and Mother Right: Selected Writings of J. J. Bachofen. Trans. Ralph Manheim. Princeton: Princeton University Press, 1973, pp. 69-207.

Barber, C. L. 1959. Shakespeare's Festive Comedy: A Study of Dramatic Form and Its Relation to Social Custom. Cleveland: Meridian, 1966.

Baring, Anne, and Jules Cashford. 1991. The Myth of the Goddess: Evolution of an Image. London: Penguin, 1993.

Barkan, Leonard. 1986. The Gods Made Flesh: Metamorphoses and the Pursuit of Paganism. New Haven: Yale University Press.

Barton, Anne. 1997. Introduction to A Midsummer Night's Dream. In The Riverside Shakespeare. $2^{\text {nd }}$ ed. Ed. G. Blakemore Evans et al. Boston: Houghton Mifflin, pp. 251-55.

Bate, Jonathan. 1993. Shakespeare and Ovid. Oxford: Clarendon Press, 1994.

Brooks, Harold F. 1979. Introduction to A Midsummer Night's Dream, The Arden Shakespeare. London: Thomson, 2003.

Calderwood, James L. 1991. A Midsummer Night's Dream: Anamorphism and Theseus' Dream. Shakespeare Quarterly, 42:409-30.

Carroll, William C. 1985. The Metamorphoses of Shakespearean Comedy. Princeton: Princeton University Press.

Chambers, E. K. 1925. Shakespeare: A Survey. New York: Hill and Wang, 1958.

Chasseguet-Smirgel, Janine. 1976. Freud and Female Sexuality. International Journal of Psychoanalysis, 57:275-86.

Coleridge, Samuel Taylor. 1811. Lectures $1808-1819$ on Literature. Ed. R. A. Foakes. In The Collected Works of Samuel Taylor Coleridge. Gen. ed. Kathleen Coburn. 16 vols. Princeton: Princeton University Press, 1987. Vol. 5, part 1.

Dunn, Allen. 1988. The Indian Boy's Dream Wherein Every Mother's Son Rehearses His Part: Shakespeare's A Midsummer Night's Dream. Shakespeare Studies, 20:15-32.

Foakes, R. A., ed. 1962. The Comedy of Errors. The Arden Shakespeare. London: Thomson, 2004.

Frazer, James George. 1890. The Golden Bough: A Study in Magic and Religion. Abridged ed. of 1922. London: Penguin, 1996.

Freake, Douglas. 1998. A Midsummer Night's Dream as a Comic Version of the Theseus Myth. In Dorothea Kehler, ed., A Midsummer Night's Dream: Critical Essays. New York: Routledge, 2001, pp. 259-74.

Freud, Sigmund. 1914. On Narcissism: An Introduction. S.E., 14:73-102. . 1919. The Uncanny. S.E., 17:219-52.

Garber, Marjorie B. 1974. Dream in Shakespeare: From Metaphor to Metamorphosis. New Haven: Yale University Press, 1975.

Gaster, Theodor H. 1969. Myth, Custom, and Legend in the Old Testament: A Comparative Study with Chapters from Sir James G. Frazer's "Folklore in the Old Testament." New York: Harper and Row.

The Geneva Bible: A Facsimile of the 1560 Edition. 1969. Madison: University of Wisconsin Press.

Goddard, Harold C. 1951. The Meaning of Shakespeare. Chicago: University of Chicago Press, 1966. 
Golding, Arthur. 1965. Ovid's Metamorphoses: The Arthur Golding Translation, 1567. Ed. John Frederick Nims. New York: Macmillan.

Graves, Robert. 1992. The Greek Myths. Combined ed. London: Penguin.

Greenacre, Phyllis. 1964. A Study on the Nature of Inspiration: Some Special Considerations Regarding the Phallic Phase. In Emotional Growth: Psychoanalytic Studies of the Gifted and a Great Variety of Other Individuals. 2 vols. New York: International Universities Press, 1971. 1:225-48.

Gui, Weston A. 1952. Bottom's Dream. American Imago, 9:251-305.

Hamilton, A. C., ed. 1977. The Faerie Queene by Edmund Spenser. Longman Annotated English Poets. London: Longman.

Hartman, Vicky Shahly. 1983. A Midsummer Night's Dream: A Gentle Concord to the Oedipal Problem. American Imago, 40:355-69.

Hartmann, Heinz. 1939. Ego Psychology and the Problem of Adaptation. Trans. David Rapaport. New York: International Universities Press, 1977.

Hinely, Jan Lawson. 1987. Expounding the Dream: Shaping Fantasies in A Midsummer Night's Dream. In Maurice Charney and Joseph Reppen, eds., Psychoanalytic Approaches to Literature and Film. Rutherford, NJ: Fairleigh Dickinson University Press, pp. 120-38.

Holland, Norman N. 1979. Hermia's Dream. In Murray M. Schwartz and Coppélia Kahn, eds., Representing Shakespeare: New Psychoanalytic Essays. Baltimore: Johns Hopkins University Press, 1982, pp. 1-20.

Humphries, Rolfe, trans. 1955. Metamorphoses by Ovid. Bloomington: Indiana University Press, 1971.

Kerényi, C. [Karl]. 1949. The Primordial Child in Primordial Times. In C. G. Jung and C. Kerényi, Essays on a Science of Mythology: The Myths of the Divine Child and the Divine Maiden. Trans. R. F. C. Hull. New York: Harper and Row, 1963, pp. 25-69.

- 1956. The Trickster in Relation to Greek Mythology. Trans. R. F. C. Hull. In Paul Radin, The Trickster: A Study in American Indian Mythology. New York: Greenwood Press, 1969, pp. 173-91.

Kott, Jan. 1987. The Bottom Translation: Marlowe and Shakespeare and the Carnival Tradition. Trans. Daniela Miedzyrzecka and Lillian Vallee. Evanston, IL: Northwestern University Press.

Loomba, Ania. 2000. The Great Indian Vanishing Trick: Colonialism, Property, and the Family in A Midsummer Night's Dream. In Dympna Callaghan, ed., A Feminist Companion to Shakespeare. Malden, MA: Blackwell, pp. 163-87.

Milton, John. 1957. Complete Poems and Major Prose. Ed. Merritt Y. Hughes. New York: Odyssey Press.

Montrose, Louis A. 1996. The Purpose of Playing: Shakespeare and the Cultural Politics of the Elizabethan Theater. Chicago: University of Chicago Press.

Ovid. 1977. Ovid 3: Metamorphoses, Books 1-8. Trans. Frank Justus Miller. Rev. G. P. Goold. Loeb Classical Library. Cambridge, MA: Harvard University Press, 2004.

- 1984. Ovid 4: Metamorphoses, Books 9-15. Trans. Frank Justus Miller. Rev. G. P. Goold. Loeb Classical Library. Cambridge, MA: Harvard University Press, 1999.

Parker, Patricia. 1996. Shakespeare from the Margins: Language, Culture, Context. Chicago: University of Chicago Press.

Shakespeare, William. 1979. A Midsummer Night's Dream. Ed. Harold F. Brooks. The Arden Shakespeare. London: Thomson, 2003.

- 1997. The Comedy of Errors. In The Riverside Shakespeare. $2^{\text {nd }}$ ed. Ed. G. Blakemore Evans et al. Boston: Houghton Mifflin.

Slights, William W. E. 1988. The Changeling in A Dream. SEL, 28:259-72.

Virgil. 1954. The Pastoral Poems (The Eclogues). Trans. E. V. Rieu. Harmondsworth, UK: Penguin.

- 2000. Aeneid, Books 7-12. Trans. H. Rushton Fairclough. Rev. G. P. Goold. Loeb Classical Library. Cambridge, MA: Harvard University Press.

Weigert-Vowin[c]kel, Edith. 1938. The Cult and Mythology of the Magna Mater from the Standpoint of Psychoanalysis. Psychiatry, 1:347-78.

Winnicott, D. W. 1971. Playing and Reality. New York: Basic Books.

Wordsworth, William. 1964. The Poetical Works of Wordsworth. Ed. Thomas Hutchinson. Rev. Ernest de Selincourt. London: Oxford University Press. 